\title{
FOREST MANAGEMENT PLAN FOR IMPLEMENTATION OF A PILOT REDD+ PROJECT FOR MASITO COMMUNITY FOREST RESERVE, KIGOMA, TANZANIA FOR 2012-2017: REVIEW OF PREVIOUS MANAGEMENT PLAN
}

\author{
Emmanuel F. Nzunda ${ }^{1}$ \\ ${ }^{1}$ Department of Forest Resources Assessment and Management, College of Forestry, Wildlife and Tourism, Sokoine Uni- \\ versity of Agriculture, Morogoro, Tanzania
}
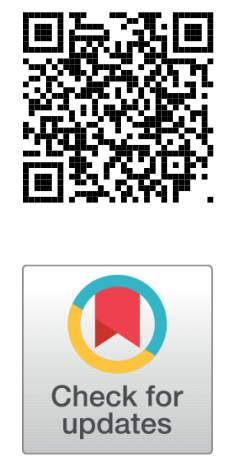

Received 3 April 2021

Accepted 18 April 2021

Published 30 April 2021

Corresponding Author

Emmanuel F. Nzunda, nzundaef@g mail.com,emmanuelnzunda@yah oo.com

DOI 10.29121/

granthaalayah.v9.i4.2021.3885

Funding: This study was sponsored by the Jane Goodall Institute.

Copyright: (C) 2021 The Author(s). This is an open access article distributed under the terms of the Creative Commons Attribution License, which permits unrestricted use, distribution, and reproduction in any medium, provided the original author and source are credited.

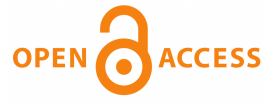

\section{ABSTRACT}

Motivation/Background: Forest management planning is an important condition for ecologically sustainable and economically efficient forest use. The current paper presents review of previous forest management plan for implementation of a pilot REDD+ project for Masito Community Forest Reserve, Kigoma, Tanzania for the period 2012-2017.

Method: The work mainly involved review of relevant documents enriched by discussions with project management.

Results: The description of the review is presented under twelve major sections, namely: 1 . review of previous forest management plan document; 2 . objectives of the previous forest management plan; 3 . achievements in implementing the previous forest management plan; 4 . challenges encountered during the implementation of the previous plan; 5 . factors that affected the implementation of the previous forest management plan; 6. survey of existing forest resources; 7. forest reserve management activities; 8 . human resources for forest reserve management; 9 . forest adjacent communities; 10 . marketing and initiatives for revenue generation; 11 . inter-sectoral linkages and co-operation, and; 12 . financial resources for management of the forest reserve.

Conclusions: The review was the basis for the activities planned for the forest for 2012-2017. Also, the review should be used as baseline information for assessment of achievement of the planned activities.

Keywords: REDD+, Forest Management Plan, Baseline, Achievements, Challenges

\section{INTRODUCTION}

Forest management planning is an important condition for ecologically sustainable and economically efficient forest use Akishin (2014). The increasing role of for- 
est management planning is based on the obvious need to transition from extensive way of forest management and use of primary natural forests to intensive way of secondary reforested forests management and use. Forest management planning in these conditions should provide the required demand in timber and other non-timber products and services. Forest management planning allows estimation of the costs of forestry activities and matching them to expected results that are really important for financial and economic management planning at enterprise level. Long-term forest management planning guarantees not only economic efficiency, but makes the grounds for forest social and ecological values protection. Forest management planning process deals with the necessity of various data collection, analysis, interpretation and application in forest management. Besides forest inventory data, forest management planning includes remote sensing data that can generate accurate and updated information about a certain forest area, allows to specify spatial, age and tree species structure of a forest stand, define a landscape and ecological peculiarities of the management planning object, mark high value forests and key biotopes. Modern information technologies based on GIS provide tools for complex analysis of information about forests and give opportunities to modelling of expected results and give an opportunity for forest management planning to select the optimal way for forest management for the specified forest.

Forest management planning must be carried out across a range of hierarchical levels (country, regional, site-specific) to ensure that the process is acceptable to all stakeholder FAO (1999). Broad scale management planning will support the identification of requirements for balancing conservation and development needs of forests and communities. Site-specific management planning will support identification of the most desirable management practices to ensure that areas are managed in a sustainable manner. An integrated approach to forest management planning requires consideration of three factors that are key to the implementation of sustainable forest management. These factors are environmental/biological/silvicultural, economic/market/finance and socio-economic. These three major factors constitute the basis, or foundation for sustainable development and assist in determining suitable landuse zones. Each consideration can be translated into country and location-specific criteria.

The first factor to be considered refers to biological and environmental issues. What is growing and can potentially grow on a particular plot of land, and what land is available for forest management. What significant features or species occur in the area? What regulatory and legal considerations exist in the area to protect various biological and environmental features? Secondly, management planning needs to also take into consideration the market, economic and financial issues. For example, will the particular area yield, in financial terms, a sufficient return? Where are the investment funds coming from and what is the cost of capital? What is the inherent value of the region for biodiversity conservation or other uses? Here, reference must be made to both traditional economics with market forecasts (domestic and external) 
and emerging valuation methodologies. These two considerations, in combination, will reduce and/or alter the options for land use. It might also be necessary to reject some options as they may not meet a set of designated criteria or the legislation.

The third set of considerations involves socio-economic criteria. These refer to people, both men and women, and their socio-economic conditions such as access to, and use of, land;land tenure (as per custom laws or custom or individual owner rights);values and beliefs; institutions and economic, political and other organisations, and; household livelihood strategies. Inherent in these criteria is the opportunity and the need for creating sustainable relations between local people who depend on the forest and the form of land use envisaged. This entails taking into consideration existing land uses. If the proposed land use denies people access to forests they customarily use, sustainability of the new land-use will be jeopardised along with the well-being of people. At the same time, this set of criteria contains a large number of interesting opportunities to work with local communities (e.g., through buffer-zone management or ecotourism development) as well as opportunities for local employment and improved communication.

The three considerations can be viewed as three layers, or filters, superimposed upon each other, with the common area defining what is possible, relevant, and sustainable to undertake. This scenario is essentially a compromise between three different considerations and their associated criteria which provides contractors/concessionaires, local forest users, and the government with a sustainable management option for that particular location. The rationale for the three major considerations in general, and the socio-economic considerations in particular, is not simply welfare of philanthropic, but relates to the need to consider all the aspects to ensure that sustainable forest use is developed successfully.

A forest management plan has five main parts, namely: 1. general description; 2. review of previous management plan; 3. management directives; 4 management prescriptions, and; 5. finances, budget, monitoring and revision. The naming and numbering of the parts may vary but the essence of their main contents usually remain the same. The current paper presents review of previous forest management plan for implementation of a pilot REDD $+{ }^{1}$ project for Masito Community Forest Reserve, Kigoma, Tanzania for the period 2012-2017. The description of the review is presented under twelve major sections, namely: 1 . review of previous forest management plan document; 2 . objectives of the previous forest management plan; 3. achievements in implementing the previous forest management plan; 4 . challenges encountered during the implementation of the previous plan; 5. factors that affected the implementation of the previous forest management plan; 6. survey of existing forest resources; 7. forest reserve management activities; 8 . human resources for forest reserve management; 9. forest adjacent communities; 10 . marketing and initiatives for revenue generation and potential values of the forest; 11 . inter-sectoral

\footnotetext{
${ }^{1}$ REDD stands for "Reducing Emissions from Deforestation and forest Degradation"; the "+" signifies the role of conservation, sustainable management of forests and enhancement of forest carbon stocks.
} 
linkages and co-operation, and; 12 . financial resources for management of the forest reserve.

\section{METHODOLOGY}

The Masito Community Forest Reserve is part of the Masito-Ugalla ecosystem located in Kigoma Region, Tanzania (Makunga and Misana (2017). The major vegetation type of the forest is miombo woodlands (Zahabu (2011 a) ). The management plan was prepared through compilation of data and information on the forest and community around. The data and information were obtained from existing literature that were prepared as part of the REDD+ project managing the forest or before the project. This paper is an excerpt from a forest management plan report that was submitted to JGI in 2012 (Nzunda (2012)).

\section{RESULTS AND DISCUSSION}

\subsection{REVIEW OF PREVIOUS FOREST MANAGEMENT PLAN DOCUMENT}

No formal previous forest management plan document existed. However, the forest was managed as a part of the conservation efforts by JGI ${ }^{2}$ for more than 15 years JGI (2009) and according to the REDD ${ }^{3}$ Project Document (RPD) since 1st January 2010.

\subsection{OBJECTIVES OF THE PREVIOUS FOREST MANAGEMENT PLAN}

According to the RPD the project aims were threefold: 1 . To generate information and lessons learned on the major drivers of deforestation in Tanzania. 2. To create carbon mitigation awareness and build capacity among stakeholders in the project area to pursue REDD related opportunities, and 3. To develop social, institutional and governance mechanisms to administer REDD related obligations and benefits.

Objective 1 was expected to be achieved through: (1) Analysis of effects of fire on carbon accounting analysed, documented and disseminated; (2) Examination of lessons learned from actions to reduce deforestation and degradation from JGI's 15 years' experience in western Tanzania analysed and documented; (3) An assessment of outcomes from all JGI REDD project activities and methodologies, including an interpretation of social, economic, institutional and policy lessons gained from the 3 year project implementation was documented and shared with relevant stakeholders. Objective 2 was expected to be achieved through: (1) Application of principles of carbon trading and REDD by stakeholders in project area (district government, village leadership, civil society, general population); (2) Formation of inter-village forest conservation $\mathrm{CBOs}^{4}$ and empowered to manage forests on general lands; (3)

\footnotetext{
${ }^{2} \mathrm{JGI}=$ The Jane Goodall Institute

${ }^{3}$ REDD was used before REDD+ and this refers to REDD and not REDD+. REDD stands for "Reducing Emissions from Deforestation and forest Degradation"

${ }^{4} \mathrm{CBO}=$ Community Based Organization
} 
Building stakeholder capacity to participate in the delivery, administration and management of REDD project sites according to national and international standards.

Objective 3 would be achieved through: (1) Development, testing and verification of a replicable and scalable methodology for remote sensing/GIS based forest and carbon accounting at village level; (2) Provision of tools and skills to monitor forest biomass and carbon stocks to communities and CBOs; (3) Development and practising of a community based equitable benefit sharing mechanism; (4) Supporting and strengthening remote sensing and GIS capacity for carbon mapping and monitoring at the national scale.

\subsection{ACHIEVEMENTS IN IMPLEMENTING THE PREVIOUS FOREST MANAGEMENT PLAN}

Towards the end of 2011, the REDD project had already registered a number of achievements including: (1) Conducting training in forest carbon sequestration principles and processes for participants being the regional and district natural resource officers, district environmental officers, community development officers, district land officers, ward/village executive officers and representatives from NonGovernmental Organisations; (2) Training on central Government policies and plans related to carbon standards and project types, including data on available markets for certified credits. The training was offered to district government officials and village government leaders; (3) Sensitisation of village leaders and the general public in targeted communities on basic principles of carbon standards and climate change. The meeting involved village government leaders, elders, religious leaders and influential people from Mpanda and Kigoma Districts; (4) Two Community Based Organisations (CBOs) had been formed to facilitate inter-village forest management. One for Mpanda, which includes five members each village of Isenaga and Bulamata and the second for Kigoma District, which included five members from Ilagala, Kirando, Songambele, Lyabusende, Sunuka, Karago and Sigunga. The CBOs will oversee all activities related to forest management and economic benefit sharing among the member villages; (5) There were ongoing radio programmes on REDD through radio KWIZERA for three years. The program aimed at sensitising and educating village leadership and the general public on REDD; (6) The project trained and equipped CBOs with knowledge in sustainable forest management practices; (7) The project facilitated assignment of forest management rights; (8) The project trained and empowered Community Forest Monitors to reduce and control risks to forest carbon from fire, inappropriate harvests, etc; (9) Conducted research to determine effects of fire on carbon accounting; (10) Conducted baseline assessment and behavioural response to carbon emission; (11) The project facilitated the process for collecting, compiling and documenting outcomes from previous JGI work and how this informs a national and Africa-wide REDD programme. 


\subsection{CHALLENGES ENCOUNTERED DURING THE IMPLEMENTATION OF THE PREVIOUS PLAN}

The challenges that were encountered during the implementation of the ongoing REDD project included: (1) Anthropogenic activities: charcoal makers, illegal timber extraction, agriculture, large herds of cattle, rampant establishment of settlements; (2) Weak law enforcement and participatory forest management (PFM); (3) Forest fires; (4) Benefit sharing mechanism was not clear; (5) Policy environment: The Government did not complete its National REDD strategy and policies for carbon market that will enable the sale of carbon credits through either voluntary carbon market or formal market; (6) Over-expectation with regards to what the carbon credits/cobenefits can do as contribution to villagers livelihoods.

\subsection{FACTORS THAT AFFECTED THE IMPLEMENTATION OF THE PREVIOUS FOREST MANAGEMENT PLAN}

On overarching factor that influences the implementation of the REDD project was the overwhelming large area that the project covers. This makes it difficult for villagers to perform patrols (they need up to 3 days walking from one end of the forest to the other). The problem of distance was compounded by lack of transport facilities, which means that the villagers had to perform the patrols on foot.

\subsection{SURVEY OF EXISTING FOREST RESOURCES}

\subsubsection{FOREST INVENTORY}

Masito Community Forest Reserve was assessed using Participatory Forest Resource Assessment (PFRA) Zahabu (2011 a) and Participatory Biodiversity Survey (PBS) JGI (2009). The PBS produced original assessments of flora and fauna composition, abundance, distribution and threats, with valuable insights from traditional knowledge of the area's biodiversity. Remote sensing analysis of 2007 multi-seasonal AWiFS and Landsat TM satellite data along with ground-truthing surveys and 60cm QuickBird imagery allowed the mapping of major vegetation types and human land uses in the MUE ${ }^{5}$. The PFRA used a modification of the sampling design used for the National Forest Resources Monitoring and Assessment Temu (2011), which follows a stratified systematic cluster sampling Zahabu (2011 a) . The design aims to reduce both costs and errors. The assessment used a cluster with 6 plots. The distance between plots within a cluster was $250 \mathrm{~m}$ whereas the distance between clusters was $5 \mathrm{~km}$. A total of 31 clusters and 186 plots were sampled.

The inventory results were summarised according to the land cover types that were identified, namely, woodland, lowland forest, bushland, grassland and cultivated land. For woodland, the dominant tree species were Brachystegia spiciformis, B. boehmii, Pericopsis angolensis, B. bussei, Diplorynchus codrocarpon, Pterocarpus tictorius, Turraea spp, P. angolensis, and Uapaca kirkiana. The dominance of Brachys-

\footnotetext{
${ }^{5}$ MUE = Masito-Ugalla Ecosystem
} 
tegia species is characteristic of miombo woodlands. The lowland vegetation type was dominated by Pericopsis angolensis, Julbernardia globifora, Pterocarpus tictorius, Diplorynchus codrocarpon, Brachystegia spiciformis, Annona spp, and Combretum spp. The appearance of some miombo species in this vegetation type indicated overlap between miombo and lowland forest types in the forest area. While the lowland forest was confined to valley bottoms, the miombo woodland was found on hill tops and shoulders. With this situation some sampled plots shared the two vegetation types. Only three tree species were found in bushland vegetation type. Grassland vegetation in Masito-Ugala REDD+ pilot area was wooded with dominant species of Brachystegia spiciformis (17\% of total biomass) and Turraea spp (8\%). Other important species in this vegetation include Brachystegia boehmii, Uapaca kirkiana and Pterocarpus angolensis. Three species of Brachystegia bussei, Pericopsis angolensis and Combretum sp) were recorded in cultivated land. These were of $\mathrm{dbh}<20 \mathrm{~cm}$ indicating recovery after clearing for agriculture.

\subsubsection{ESTIMATED CARBON BENEFITS OF MASITO-UGALA REDD PILOT AREA}

This section presents estimates of the carbon benefits of the Masito-Ugala forest. REDD+ entails about five components, namely: (1) avoided deforestation; (2) avoided degradation; (3) carbon sequestration; (4) sustainable forest management, and (5) forest conservation.

Before conserving the Masito Ugala forest, there was rampant charcoal production, agricultural expansion, and timber harvesting taking place inside the forest. That means the forest faced both deforestation and degradation. Without this project these activities were expected to continue. This study determined the present carbon stocks in the identified forest cover types. Applying a rate of sequestration of $2.4 \mathrm{~m}^{3}$ / ha Yanda (2010b) with a conservative degradation estimate of 1 ton biomass/ha/year (yielding 0.5 ton of carbon), the carbon benefit from avoidance of degradation and carbon sequestration was computed. Table 1 shows that at the price of $\$ 5$ per $\mathrm{tCO}_{2}, \mathrm{CO}_{2}$ sequestration due to forest restoration alone in two years would be worth about $\$ 1,660,514$. These estimates however, included only the tree carbon estimates.

\subsubsection{FOREST MAPS}

There are maps showing the boundary of the Masito Community Forest Reserve (MCFR) and the villages neighbouring the forest as points and maps that show the distribution of biomass, vegetation types and human land use within the forest and its surrounding landscape Baccini et al. (2007), JGI (2009). Furthermore, there are maps of land use plans for seven villages that are involved in the management of the MCFR in two formats: 3 dimensional (3D) models Mwanukuzi (2011) and conventional maps (These maps cover village land areas outside MCFR). NAFORMA was also working on land use mapping for the whole country and their data was used to 
Table 1 Estimated carbon benefits due to avoidance of degradation and sequestration in Masito-Ugala forest. Source: Zahabu 2011a.

\begin{tabular}{|c|c|c|c|c|c|c|c|c|}
\hline $\begin{array}{l}\text { Land } \\
\text { cover } \\
\text { type }\end{array}$ & $\begin{array}{c}\text { Area } \\
\text { (ha) }\end{array}$ & $\begin{array}{c}\mathrm{CO}_{2} \\
\text { Eq. } \\
\text { (t/ha) }\end{array}$ & SE & $\begin{array}{l}\mathrm{CO}_{2} \text { eq } \\
\text { Branches } \\
\text { \& Twigs }\end{array}$ & $\begin{array}{c}\text { Total } \\
\text { Above } \\
\text { Ground } \\
\mathrm{CO}_{2} \text { Eq (t) }\end{array}$ & $\begin{array}{c}\text { Total } \\
\text { Below } \\
\text { Ground } \\
\mathrm{CO}_{2} \text { Eq } \\
\text { (t) }\end{array}$ & $\begin{array}{c}\text { Total } \\
\text { tree } \\
\mathrm{CO}_{2}(\mathrm{t})\end{array}$ & $\begin{array}{l}\text { Total } \\
\text { tree } \mathrm{CO}_{2} \\
\text { eq in } 2 \\
\text { yrs }\end{array}$ \\
\hline $\begin{array}{l}\text { Woodland } \\
\text { (Miombo } \\
\text { wood- } \\
\text { land) }\end{array}$ & 67,200 & 62.8 & 9.1 & 16.96 & $5,360,457$ & $1,072,091$ & $6,432,548$ & $6,679,172$ \\
\hline Grassland & 17,819 & 17.5 & 5.72 & 4.71 & 395,122 & 79,024 & 474,146 & 539,542 \\
\hline $\begin{array}{c}\text { Forest } \\
\text { (Low- } \\
\text { land } \\
\text { Forest) }\end{array}$ & 3,837 & 144 & 46.5 & 38.86 & 701,418 & 140,284 & 841,702 & 855,784 \\
\hline $\begin{array}{l}\text { Others } \\
\text { (Settle- } \\
\text { men- } \\
\text { t/Burn/Sh } \\
\text { ow/- } \\
\text { Clouds) }\end{array}$ & 942 & 4.35 & & 1.17 & 5,204 & 1,041 & 6,245 & 9,702 \\
\hline Bushland & 524 & 23.8 & 29.3 & 6.43 & 15,838 & 3,168 & 19,006 & 20,929 \\
\hline $\begin{array}{l}\text { Cultivated } \\
\text { land }\end{array}$ & 169 & 4.35 & & 1.17 & 934 & 187 & 1,120 & 1,741 \\
\hline $\begin{array}{c}\text { Open } \\
\text { (Barren) }\end{array}$ & 0.22 & 0 & & 0 & - & - & & - \\
\hline Total & 90,491 & & & & & & $7,774,768$ & $8,106,870$ \\
\hline
\end{tabular}

produce land use maps covering MCFR for the year 2010. There was no analysis of changes in land use and forest cover. That was an ongoing activity the outputs of which were yet to be produced.

\subsection{FOREST RESERVE MANAGEMENT ACTIVITIES}

\subsubsection{BOUNDARY CONSOLIDATION}

The boundary of the MCFR was mapped and forest monitors (FM) had the maps on GPS that were used during patrols. On the ground, the boundary was recognised using natural features. There are neither beacons nor trenches to mark the boundary of the forest.

\subsubsection{FOREST PROTECTION}

Scheduled patrols are conducted by FM four times a month, on days that are arranged by the security committee of JUWAMMA ${ }^{6}$. There are no fire lines currently, however there are by-laws that emphasise appropriate use of fire and discourage people from

\footnotetext{
${ }^{6}$ JUWAMMA is Swahili for Jumuiya ya Watunza Msitu wa Masito, which in English is Community of Masito Forest Managers.
} 
setting fire into the forest. In addition to the regular patrols, the FM respond to any alarm that was raised by the occurrence of an unacceptable event in the forest such as a fire or when there are domestic animals in the MCFR. The decision to conserve MCFR reduced significantly the utilisation forest by adjacent communities who are now interested in getting money from the sale of carbon credits.

Forest Monitors (FM) in collaboration with villagers in general put their effort in arresting illegal harvesting from MCFR. A total of 30 FM was empowered and fully engaged in forest patrol and always giving feedback to the relevant authority about the situation in the forest including activities related to agriculture, charcoal making and timber extraction. For example, In February 2011, FM in collaboration with CBO members from Karago and Songambele villages conducted joint forest patrol, arrested eight men with four chainsaws and 70 bags of charcoal JGI (2011 a). In another occasion, FM were able to confiscate and give penalty to 50 bags of charcoal that were impounded and total of TZS $350,000^{7}$ accrued as a royalty to FBD and District Council. This was achieved with support from Kigoma Rural District Forest Officer and other district staff.

\subsubsection{FOREST RESTOCKING AND NATURAL REGENERATION}

Since the forest regenerates very effectively from sprouts, it does not need any planting. All that was needed was to protect the forest so as to allow natural regeneration to take place. Thus, efforts that had so far been done concerning forest protection were geared at reduction of pressure from human and livestock use of the forest and prevention of fire so as to facilitate natural regeneration in MCFR.

\subsubsection{NURSERIES}

No nurseries were established in relation to the REDD+ project for MCFR because no seedlings are needed. Both the MCFR and the forests within the village lands can effectively regenerate naturally.

\subsubsection{MANAGEMENT OF BUFFER ZONES AND CORRIDORS}

The MCFR was located in such a way that most of the villages are arranged on the west side towards the lake. For management of the village lands, land use plans were prepared for the seven villages involved in the REDD+ project. The land use plans for each village include forest for utilisation by villagers as one of the categories of the land uses. Much of the MCFR on the eastern, northern and southern sides was connected to other forest, which provides ecological connectivity of one form or another.

\footnotetext{
${ }^{7}$ USS = 1,575.00 TZS (Tanzania Shilling) as at 31st December 2012
} 


\subsubsection{WATERSHED AREAS MANAGEMENT AND SOIL CONSERVATION}

Efforts for watershed areas management and soil conservation were included in the management of the VLFRs and thus the MCFR. For example, the by-laws forbid digging in VLFRs, which was a good measure against soil erosion. Other measures against soil erosion are restrictions against use of the MCFR for grazing and cultivation.

\subsubsection{PHYSICAL RESOURCES}

The MCFR REDD forest management project was run from a hired office in Kigoma town. There was one vehicle, a Toyota Land Cruiser four-wheel drive, which was used by the project management team to facilitate the management of the forest. There was no office for forest management on site. JUWAMMA conducts its meetings in village office buildings JUWAMMA (n.d.). To facilitate forest patrols and assessments, GPS units and Android phones were bought and supplied to FM.

\subsection{HUMAN RESOURCES FOR FOREST RESERVE MANAGEMENT}

\subsubsection{STAFF}

The REDD project was managed by the Director of Programmes who was assisted by the Project Accountant, Project Assistant and Community Development Officer. The Director had a master's degree whereas all his assistants had bachelor's degrees. There was need for a Forest Officer and a Monitoring and Evaluation Officer, the incumbents of both posts left the project. Project activities were also facilitated by District officers of different fields depending on need. For instance, the District Beekeeping Officer, the District Lands Officer and the District Forest Officer had assisted on issues related to beekeeping, lands and forest management respectively. On site, the forest was managed by JUWAMMA, which had a total of 35 members. The members were trained in use of GPS, Android phones and forest management to enhance their effectiveness in forest management.

\subsubsection{TRAINING}

Training focussed on increasing awareness of the local communities on the negative effects of uncontrolled forest utilisation, benefits of proper forest management and alternative income generating activities so as to divert pressure from unsustainable forest utilization. In addition, training aimed at increasing the capacity of JUWAMMA and the community to participate in management of MCF by increasing their technical knowledge relevant for forest management. Specifically, communities were trained on forest protection, modern beekeeping, good governance, participatory mapping, carbon assessment and carbon sequestration and storage processes, carbon marketing and REDD and business management, customer care and marketing skills Luoga (2010), Yanda (2010a), HWK (2011), JGI (2011 a), Mwanukuzi 
(2011), Njahani (2010), Temu (2011), Zahabu (2011 a).

\subsection{FOREST ADJACENT COMMUNITIES}

\subsubsection{COMMUNITY ORGANISATIONS AND INSTITUTIONS}

The MCFR was managed by a Community Based Organisation called JUWAMMA (Jumuiya ya Watunza Msitu wa Masito). JUWAMMA comprise members from seven villages, namely, Ilagala, Kirando, Songambele, Lyabusende, Sunuka, Karago and Sigunga. Specifically, members of JUWAMMA comprise five members of Village Environmental Committees of each of the seven villages making the total number of members 35 . JUWAMMA was formally launched in 2011 and it had a functional constitution (JUWAMMA, no date). JUWAMMA was organised in such a way that it had a General Council that oversaw three committees, namely, the Defence and Security Committee, the Central Committee and the Planning and Finance Committee and any other permanent or temporary committees that may be formed by the General Council as deemed appropriate for the development of JUWAMMA. The General Council was led by a Chairperson, a Secretary and a Bursar. Each of the committees was led by a Chairperson and a Secretary.

JUWMMA's activities are guided by their objectives, which are stipulated in the constitution as follows: (1) To conserve, protect and manage the forest so as to make it an exemplary forest for REDD+; (2) To prepare a forest management plan; (3) To oversee the fulfilment of the requirements for carbon credits for MCFR under REDD+; (4) To present statistics to appropriate authorities and market carbon credits; (5) To market and control the marketing of other natural resources that may be marketable from MCFR; (6) To manage and control revenues from carbon sales and other products from MCFR (7) To represent member villages in all matters pertaining to REDD+ for MCFR when dealing with other levels of the government, NGOs and investors. Such matters may include: (1) Strengthening, maintaining and protection of good relations among member villages, the government and other organisations; (2) Protection and management of boundaries of the MCFR with member villages and neighbouring villages; (3) To reinforce regulations and rules for conservation of the MCFR; (4) Any other matters that will contribute to development of the communities in general provided they are granted by the law

Apart from JUWAMMA, there are other community-based and non-communitybased organisations that operate in the MCFR REDD project area, which are hightlighted in Table 2. Kigoma District Council and the JGI REDD+ project are also important institutions operating in the area.

\subsubsection{INSTRUMENTS TO FACILITATE COMMUNITY PARTICIPATION}

JUWAMMA prepared by-laws for the management of Masito Community Forest Reserve (MCFR) . In addition to the by-laws for management of MCFR there are also by-laws for forest management for each village as part of Village Land Use Plan. 
Table 2 Organisations operating in the MCFR REDD project area. Source: ACHRID, 2011.

\begin{tabular}{|c|c|c|c|}
\hline Village & Agency/Program & $\begin{array}{c}\text { Type of } \\
\text { Intervention(s) }\end{array}$ & Coverage \\
\hline \multirow[t]{9}{*}{ Ilagala } & KIOO & $\begin{array}{c}\text { Education on } \\
\text { HIV/AIDS }\end{array}$ & Ilagala village \\
\hline & Mwangwi SACCOS & Provision of loans & Ilagala village \\
\hline & Yataka Moyo Group & $\begin{array}{l}\text { Promotion of } \\
\text { cultivation of palm } \\
\text { trees whereby the } \\
\text { palm oil was } \\
\text { expected to be used } \\
\text { for production of } \\
\text { electricity }\end{array}$ & Ilagala village \\
\hline & JUWAMMA CBO & $\begin{array}{c}\text { Inter-village CBO } \\
\text { for management of } \\
\text { Masito Ugalla forest } \\
\text { conservation in the } \\
\text { project area }\end{array}$ & $\begin{array}{l}\text { All seven (7) REDD } \\
\text { Project villages }\end{array}$ \\
\hline & $\begin{array}{c}\text { Lake Tanganyika } \\
\text { Basin }\end{array}$ & $\begin{array}{l}\text { Income Generating } \\
\text { Activities and } \\
\text { Conservation of } \\
\text { Lake Tanganyika } \\
\text { Basin }\end{array}$ & Ilagala village \\
\hline & Police & $\begin{array}{l}\text { Security/law and } \\
\text { order }\end{array}$ & Ilagala village \\
\hline & Court and prison & Law and order & Ilagala village \\
\hline & Schools & Education & Ilagala village \\
\hline & $\begin{array}{c}\text { Churches and } \\
\text { mosques }\end{array}$ & $\begin{array}{l}\text { Maintaining peace } \\
\text { and harmony }\end{array}$ & Ilagala village \\
\hline \multirow[t]{2}{*}{ Songambele } & $\begin{array}{l}\text { Gombe MUE } \\
\text { Programme }\end{array}$ & Forest conservation & MUE area \\
\hline & $\begin{array}{l}\text { CARITAS - Kigoma } \\
\text { Catholic Diocese }\end{array}$ & $\begin{array}{l}\text { Land use planning } \\
\text { support }\end{array}$ & Songambele village \\
\hline \multirow[t]{5}{*}{ Kirando } & Luguvu CBO & $\begin{array}{c}\text { Beekeeping and } \\
\text { forest conservation }\end{array}$ & Kirando \\
\hline & SACCOS & Provision of loans & Kirando \\
\hline & ATIME & Traditional healing & Kirando \\
\hline & Harbour/port & Transportation & Kirando village \\
\hline & Military base & Defence & Kirando \\
\hline
\end{tabular}

The by-laws for MCFR clearly stipulate what may be and may not be done within the MCFR and the fines for contravening the by-laws. Especially, it was clearly stated that the MCFR was primarily for conservation for participation in REDD+ carbon credit marketing. The by-laws also specify the rights and responsibilities of individual and institutional stakeholders to MCFR. 


\subsubsection{EXTENSION SERVICES AND SOCIO-ECONOMIC STUDIES}

Part of the extension services was provided through the training efforts described in section 3.8.2 above. In addition to training awareness was enhanced through the use of posters, radio programmes and TV and video programmes and drama JGI (2011). Public awareness and knowledge campaigns related to climate change, carbon sequestration and good governance and forest management were aired through Star TV and Radio free Africa. Interactive video shows were conducted in three villages bordering the Masito Ugalla ecosystem (Kazulamimba, Chakuru and Uvinza). The video shows contained messages on fire management, unsustainable harvest of timber and benefits from REDD initiatives. About 1108 (330 Female, 778 Male) people attended these interactive video shows. "Mapigo saba" drama group conducted shows in Karago, Sunuka and Songambele villages. The aim was to sensitize communities to reduce the driver of deforestation and forest degradation such as charcoal making, tree cutting, bush fire and shifting cultivation. In addition, the theater art emphasized the issue of involving gender in income generating activities at household level that would reduce pressure from the forest. The message encouraged joining the beekeeping groups in order to secure additional income for their families. About 678 (450F, 228M) people attended the shows. A total of 2000 copies of awareness creation posters were developed, printed and disseminated.

A very detailed socio-economic study was conducted to establish baseline information for assessment of behaviour change regarding forest degradation and loss, carbon emission reduction risks, opportunities and benefits for REDD Project in Masito Ugalla Ecosystem ACHRID (2011) Main methods used in data collection for the study were focus group discussions (FGD), semi-structured interviews with key informants, household questionnaire survey, field observations and literature review. FGD use participatory rural appraisal (PRA) methods, namely, resource maps, historical timelines, seasonal calendars, gender analysis, which were later supplemented by the information collected through semi-structured interviews and household survey. Literature reviewed covered documents related to the project including project proposal, training and progress reports, Kigoma District Council (KDC) profile, village records and internet-based sources. Focal areas considered in the study were: (1) Demographic features including population and density, migration patterns, ethnic groupings, age, gender distribution; (2) Livelihood occupations; (3) Education levels of the respondents; (4) Use and tenure of natural resources including land, water and forests; (5) Land ownership (acreage) and use; (6) Forest resources utilisation regulations; (7) Opportunities and benefits of REDD interventions and; (8) Institutions/agencies in project area.

\subsubsection{SOCIAL NETWORKS}

Most important and common social networks existing in the project areas are mutual support groups formed on diverse basis ranging from neighbourhood, ethnic affili- 
ations to friendship ACHRID (2011). Members of most of these groups are women who regard their informal associations as a dependable source of self-help. Members enter into agreement of contributing small amounts of money and distribute it to each member on rotational basis. The practice was locally known as "Mchezo". There are also socio-economic groups consisting of male and female membership, which are mainly for enterprising purposes such as beekeeping. Other social groups include hunting parties and entertainment groups.

\subsubsection{EDUCATIONAL ATTAINMENT}

Most of the respondents (64.6\%) had attained primary school education, while only $3.8 \%$ had secondary education ACHRID (2011). This was partly because few secondary schools exist in the project area. Additionally, a significant number of the respondents (31.6\%) had no formal education at all. There were more men (69.9\%) than women (30.1) with at least primary education. The same pattern was observed for secondary education, whereby $69.2 \%$ men vs $30.8 \%$ women had attained secondary education. Also, majority of women respondents $(60.7 \%)$ had no formal education whereas for men without formal education were fewer (39.3\%). The marginalisation of women in terms of educational attainment was likely to result in more costs and less benefits from participating in project interventions compared to men. Generally, these statistics indicate low level of literacy among the local population.

\subsubsection{GENDER RELATIONS}

During community visioning exercises in which men and women were mixed, most women were not actively participating in the discussions unless they were pinpointed to do so ACHRID (2011). This culture of silence among women was on one hand due to traditions and customs as explained by key informants in the villages which generally prevent them from talking in front of men especially during public meetings. Records from the study villages on the gender composition in village goverment leadership indicate that women representation was $32 \%$ (8 out of 17 for each of the Ilagala, Songambele and Kirando villages) of the total number of members. However, it was noted that all women representatives in the village government leadership were appointed for special seats implying that women hardly vie for leadership positions on their own initiatives.

As observed earlier the level of education of women respondents was low relative to their male counterparts and as such their participation in public discussion was limited as they are not broadly informed of issues. In addition, it was explained that women attendance to various community meetings was low compared to men as they had to attend other pressing domestic chores.

Regarding who controls and own most of the household assets most discussants in female and male FGD meetings asserted that in the Ha ethnic social system, traditions 
and customs dictate that men are the owners and controllers of nearly all domestic assets with the exception of things like a hoe and cooking utensils over which women had access in fulfilling their domestic chores. As such in tradition of the Ha the man controls all household resources and income generated, and generally (84\%) was the main decision maker, even where the woman's contribution to the household economy was half or more

\subsubsection{LIVING STANDARDS IN THE PROJECT AREA}

Living standards were assessed using home ownership, type and conditions of residential houses, asset ownership, source of energy and access to social services as indicators. The household survey indicates that 293 (86.4\%) out of 339 household respondents live in their own houses while $9.7 \%$ live in rented houses and the remaining 3.8\% live with relatives. Grass thatched houses comprised 59.3\% whereas $40.7 \%$ had roofs of corrugated iron sheets. The walls of most houses are of mud bricks which constitute $47.8 \%$ whereas $40.7 \%$ were of burnt brick walls, $8 \%$ of mud and poles, $2.9 \%$ of poles and $0.6 \%$ of grass or palm leaves. The majority of the households (85.8\%) had houses with mud floor while the rest (14.2\%) are cement floored. The analysis of the types of houses above as well as the ACHRID team's observation indicated that nearly all residents were permanently settled and hence had a stake to actively participate in socioeconomic development activities initiated in the project area. Moreover, the relatively high percentage of households with houses roofed with corrugated iron sheets (40.7\%) and those with burnt bricks walls (40.7\%) indicates that their socio-economic status was of better quality. The extent to which local people use the forest products such as poles, wood, and firewood for brick burning need further studies to examine their implications to forest conservation initiatives.

In terms of possession of various assets as a non-monetary income measurement of the wellbeing of individual households $62.8 \%$ of the respondents possess a radio, $48.1 \%$ a bicycle, $38.3 \%$ a bed with mattress, $35.1 \%$ a mobile phone handset, and $38.3 \%$ home furniture such as tables and chairs. Though respondents did not mention ownership of hoes or machetes perhaps because these are considered as basic domestic assets, it was evident from the fact that the major economic occupation in the project area was small scale farming that most of the residents possessed them.

Firewood and charcoal are the major sources of energy mainly for cooking purposes. The former was used by about $88.5 \%$ and the latter $25.7 \%$ of the population. A few people use kerosene (1.2\%), electricity $(0.9 \%)$, gas $(0.6 \%)$ implying that trees had to be felled in order to meet day today requirements of fuel wood. For source of light, about $96.8 \%$ of the households use kerosene either in hurricane lamps or vibatali and at times supplemented by other sources like battery-powered torch $(9.7 \%)$, solar power $(1.5 \%)$ and mineral oil powered generator $1.2 \%$. A neglible $0.6 \%$ use electricity from Tanzania Electric Supply Company Limited (TANESCO). The implications of large dependency on wood for source of energy depicted by these results on REDD+ need further study. 
The low level of educational attainment was related to the limited number of schools and insuffiency of teachers and teaching facilities in the project area. There was a total of 27 primary schools in the project area of which ten are located in Ilagala village, four in Karago, five in Sunuka, three in Kirando, two in Lyabusende and two in Sigunga village. Primary education was however constrained by insufficient qualified teachers, classrooms and staff houses. For example, Songambele and Anzarani primary schools in Songambele village had two teachers and one teacher respectively. The schools did not have adequate classrooms and desks to the extent that pupils had to study outdoors. Furthermore, teaching materials such as textbooks are scarce.

Secondary education was accessed from two-day secondary schools located in Ilagala and Sunuka villages which compel students from other villages to travel long distances. Similar to primary education, secondary education was challenged by insufficient qualified teachers, classrooms and staff houses. Such unfavourable school environment affects not only pupils' performance but also encourages absenteeism and, increased dropout rates. The result was that some school leavers cannot read nor write. This means there was high rate of illiteracy in the area, which limits the ability of the majority to participate in written communication.

With the exception of Sunuka village which was served by one piped water scheme, the major sources of water for domestic use in the project area are the lake, rivers, ponds and open traditional wells. Residents of all villages except Songambele access water for different uses from Lake Tanganyika. Other main sources of water include Malagarasi River which mainly serves residents in Ilagala village, and other minor rivers such as Luguvu and Nyankima in Kirando village, Anzarani, Gambazi, Ilolo, Msumbuzi and Mkanga in Songambele village, Mbezi and Ruguvu in Kirando village. In addition to these sources where water was accessed free of charge the study observed that in some households especially in trading centres such as Lugongoni sub-village and Machazo sub-village in Ilagala village access water from water vendors at a price of Tanzania shillings 200-300 a 20-litre jerry-can. The major water supply concerns as expressed by most of the interviewees included long distances to water sources, high prices charged by water vendors, unsafe water which causes waterborne diseases such as diarrhoea, typhoid and frequent cholera outbreaks.

There was one dispensary in each of the seven villages which in principle was to provide both preventive and curative services. However, the study noted from different discussion forums that residents in the project area faced a number of constraints related to poor health services of which the following are most common and critical: (1) Scarcity of human drugs and other medical facilities in the dispensaries; (2) Acute shortage of qualified medical staff; (3) Long distances to the nearest static health facilities (SHF); (4) Inaccessibility to referral services especially for poor families as the nearest referral hospital was in Kigoma Municipality, and; (5) General poverty which inhibits many families from accessing medical services or buying drugs from 
privately owned local pharmacies

The above commonly expressed health related constraints had undoubtedly resulted in a significant number of people (53.7\%) opting for traditional herbs which can be easily accessed in the forests or bushes around the villages. From wealth ranking exercise, it was learned that households in the low and middle wealth ranks are more dependent on herbal medicine that those in the high wealth ranks.

The project area had one rough main road that linked it to the district headquarters in Kigoma town where the REDD+ project office was located. Distances from project villages to the district headquarters vary with the farthest village that was Sigunga situated about 140 kilometres and the nearest - Ilagala village - about 71 kilometres. The main road ends at Ilagala village whereby the only link to the rest of the project villages was by crossing River Malagarasi either by ferry or small boats. The project villages had rough feeder roads that enable residents to reach the ferry so as to get to the main road at Ilagala village. Both the main and the other feeder roads are not always passable especially during the rainy season. Some sub villages such Ilolo in Songambele village and Mahanga in Ilagala village cannot be accessed at all by motor vehicles as there are no roads. The only means of transport to these areas was either by bicycle or motor cycle. Water transport for both cargo and people in Lake Tanganyika was also used to link the project area with Kigoma town and the DRC from a small port in Kirando village. There was a daily bus service from Kigoma town to Ilagala village.

There are no postal services in the project area. Furthermore, cellular phone communication services are not easily accessible in most of the project villages with the exception of Ilagala village especially in Lugongoni trading centre where network reception through Vodacom and Airtel was relatively clear. Residents with mobile phone handsets in other project villages where the signal was weak had either to climb up trees or hills in order to communicate with the outside world. In these circumstances information to and from Kigoma town and elsewhere outside the project villages was normally delivered by travelling using bicycles, motorcycles and public transport. Due to the poor condition of the main and feeder roads communication becomes cumbersome especially during the rain seasons. Communication through the radio can be more effective for the project given that $62.8 \%$ of the respondents possess a radio set. Radio reception was clear especially via the local stations specifically Radio Kwizera and Radio Free Africa (RFA). The effects of poor communication cannot be overemphasised for a project such as REDD which information sharing between the target communities and the project management was one of the key prerequisites especially in forest monitoring. For example, with poor communication patrol in forest reserves cannot be effective. 


\subsubsection{KNOWLEDGE, ATTITUDES AND PRACTICE TOWARDS FOREST CONSERVATION}

Residents in the project area had varying levels of knowledge and attitudes towards forest conservation especially among men and women. The difference between people that were aware (52.5\%) and those that were not aware $(47.5 \%)$ of land use planning was insignificant. This despite the fact that at different periods in the past some agencies such as CARITAS Kigoma, MUE program and KDC had facilitated land use planning in these study villages.

According to the information from key informants in KDC and REDD project land use planning involved only top local leaders specifically VG chairpersons, VEOs, subvillage chairpersons, divisional secretaries, selected leaders of Faith Based Organisations (FBOs), and members of Village Environment Committees. FGD and key informants attributed the low level of knowledge of the existence of land use plans to three main reasons namely lack of feedback mechanism from village leadership to local communities, low turnout at community meetings and the general low level of education among the local population including the local leaders which inhibits their understanding and delivery of right information. However, in proportionate terms women respondents were generally less knowledgeable (only $24.8 \%$ were aware) than men $(75.2 \%$ were aware) of the existence of land use plans. Due to low awareness of land use plans, there was a risk of encroaching the forest reserves and consequently degrade them. There was also a tendency of people to unconsciously think that the available land in their villages can be used for any purpose of their choice.

In order to establish the current practices towards forest degradation and loss the study assessed the level of respondents' awareness on the activities undertaken in and around the forest reserves. Through household survey, the main activities mentioned include timber/poles extraction/logging (83.5\%), cultivation (82\%), firewood collection (65.5\%), beekeeping/honey collection (63.7\%), grazing (55.8\%), charcoal burning (54.6\%), water collection (54.6\%), collection of medicinal herbs (53.7\%), wild fruits collection $(49.3 \%)$, hunting $(39.5 \%)$, distilling of local spirit (27.4\%), conducting rituals (20.9\%) and tourism/picnicking/camping (36.3\%). Although most of the activities done by men and women in and around the forests were generally similar, the purpose was different. While most of the women activities such as mushroom collection, grass cutting, water collection, and collection of medicinal herbs were predominantly meant for domestic use, men were engaged in similar activities for sale for income purposes. For some reasons activities such as forest monitoring, charcoal burning, timber/poles harvesting and hunting were done by men. Women were exempted from forest monitoring because of the high risks that were indirectly associated with the activity such as attacks by wild animals and poachers and rape. Communities in the entire project area were in many aspects involved in forest related activities for their livelihood and as such forests were regarded as their lifeline asset. However, uncontrolled use of forest resources depletes forest utility and this raises concern on the future of their 
livelihood security

\subsection{MARKETING AND INITIATIVES FOR REVENUE GENERATION}

Marketing and revenue generation related to MCF had two facets: one based on MCF itself and the other based on other forests and activities within the MCF REDD+ project area. So far the REDD+ project had not implemented any actual marketing and generation of income from both the two facets. However, the advertisements on the MCF forest and its potential for income generation through REDD+ may be considered a marketing initiative. In connection to that initiative, potential carbon benefit was estimated for the forest as shown in section 3.6.2. As for the sources of revenue other than the MCF itself, there were efforts to promote modern beekeeping, business management and customer care skills through awareness campaigns and training as described in section 3.8.2.

\subsection{INTER-SECTORAL LINKAGES AND CO-OPERATION}

The REDD+ project works closely with the KDC through its various sectors. For example, the Kigoma District Lands Sector facilitated land use planning for all the seven villages. The district Beekeeping Sector facilitated training on modern beekeeping and was involved in facilitation to supply needed beekeeping gear.

\subsection{FINANCIAL RESOURCES FOR MANAGEMENT OF THE FOREST RESERVE}

Apart from the revenue that accrued from the payment of penalty from illegal forest uses, REDD+ project had not created any revenues from management of MCF. The finances for operation of the project came from the sponsors of the project.

\section{CONCLUSIONS AND RECOMMENDATIONS}

The following main conclusions are drawn from the present study:

- No formal previous forest management plan document existed.

- The objectives of previous forest management were: 1 . To generate information and lessons learned on the major drivers of deforestation in Tanzania. 2. To create carbon mitigation awareness and build capacity among stakeholders in the project area to pursue REDD related opportunities, and 3. To develop social, institutional and governance mechanisms to administer REDD related obligations and benefits.

- The previous forest management REDD project registered a number of achievements including: training of regional and district natural resource officers, district environmental officers, community development officers, district land officers, ward/village executive officers and representatives from NonGovernmental Organisations and local forest adjacent communities; formation 
of two Community Based Organisations (CBOs) to facilitate inter-village forest management; conducting radio programmes on REDD; The project facilitated assignment of forest management rights; The project trained and empowered Community Forest Monitors to reduce and control risks to forest carbon from fire, inappropriate harvests, etc; Conducted research to determine effects of fire on carbon accounting, baseline and behavioural response to carbon emission; The project facilitated the process for collecting, compiling and documenting outcomes from previous JGI work and how this informs a national and Africa-wide REDD programme.

- The challenges that were encountered during the implementation of the ongoing REDD project included: Anthropogenic disturbances; Weak law enforcement and participatory forest management; Forest fires; benefit sharing mechanism was not clear; the government had not yet completed the National REDD strategy and policies for carbon market that would enable the sale of carbon credits through either voluntary carbon market or formal market; overexpectation with regards to what the carbon credits/co-benefits can do as contribution to villagers livelihoods.

- Villagers had to patrol the forest on food due to lack of transport facilities for forest management for villagers. The forest area to be patrolled was so large that they would need 3 days to walk around the circumference of the forest.

- The forest had been inventoried and its carbon values estimated. Maps of the forest also existed.

- The boundary of the MCFR was mapped and forest monitors (FM) had the maps on GPS that were used during patrols.

- Scheduled patrols were conducted by forest monitors four times a month, on days that were arranged by the security committee of JUWAMMA.

- Since the forest regenerates very effectively from sprouts, it did not need any planting. No nurseries were established in relation to the REDD+ project for MCFR because no seedlings were needed.

- The MCFR was managed by a Community Based Organisation called JUWAMMA (Jumuiya ya Watunza Msitu wa Masito). JUWAMMA comprise members from seven villages.

- JUWAMMA prepared by-laws for the management of Masito Community Forest Reserve (MCFR). In addition to the by-laws for management of MCFR there are also by-laws for forest management for each village as part of Village Land Use Plan. The by-laws for MCFR clearly stipulate what may be and may not be done within the MCFR and the fines for contravening the by-laws.

- Most important and common social networks existing in the project areas are mutual support groups formed on diverse basis ranging from neighbourhood, ethnic affiliations to friendship. 
- Most of the respondents (64.6\%) had attained primary school education, while only $3.8 \%$ had secondary education.

- During community visioning exercises in which men and women were mixed, most women were not actively participating in the discussions unless they were pinpointed to do so. This culture of silence among women was due to traditions and customs which generally prevent women from talking in front of men especially during public meetings.

- Nearly all residents were permanently settled and hence had a stake to actively participate in socioeconomic development activities initiated in the project area.

- The low level of educational attainment was related to the limited number of schools and insufficiency of teachers and teaching facilities in the project area.

- Residents in the project area had varying levels of knowledge and attitudes towards forest conservation especially among men and women.

- The REDD project had not implemented any actual marketing and generation of income from the forest. Thus the project had not created any revenues from management of MCF. The finances for operation of the project came from the sponsors of the project.

- The REDD+ project works closely with the KDC through its various sectors.

- This review of the previous forest management plan formed the baseline status of the forest management for the study area. This is important for assessment of the same items reviewed after implementation of the planned activities during the plan period of 2012-2017.

- The review of the previous management plan was also the basis of the planned activities for the planning period.

- Given the broad interest in forest management planning, the breadth and depth of the information covered in this review for various sectors relevant for sustainable development and the strategic significance of the study area for conservation, this paper should be of interest to broad readership.

\section{ACKNOWLEDGEMENTS}

The author thanks the Jane Goodall Institute who sponsored the study.

\section{REFERENCES}

ACHRID. (2011). Baseline Assessment Of Behaviour Change Regarding Forest Degradation And Loss, Carbon Emission Reduction Risks, Opportunities And Benefits For REDD Project In Masito Ugalla Ecosystem Kigoma.

Akishin, V. (2014). Forest Planning As The Most Important Aspect Of Sustainable Forest Management. ERSA Conference Papers Ersa14p569. European Regional Science Association. 
Baccini, , et al. (2007). A First Map Of Tropical Africa's Above-Ground Biomass Derived From Satellite Imagery. Environmental Research Letters, 3, 4-4.

FAO. (1999). Code Of Practice For Forest Harvesting In Asia-Pacific. Code Of Practice For Forest Harvesting In Asia-Pacific. Asia - Pacific Forestry Commission. Retrieved from Http:// Www.Fao.Org/3/Ac142e/Ac142e00.Htm\#Contents

HWK. (2011). Taarifa Ya Mafunzo Kwa Wafugaji Nyuki Katika Eneo La Mradi Wa MKUHUMI Yaliyofanyika Ilagala Kuanzia Tarehe 15-20 Agosti 2011. In T. Y. M. K. W. N. K. E. L. M. W. M. Y. I. K. T. .-. A. . H. Y. W. K. (HWK (Ed.), .

JGI. (2009). Building REDD Readiness In The Masito Ugalla Ecosystem Pilot Area In Support Of Tanzania's National REDD Strategy. A Proposal Submitted By The Jane Goodall Insititute (JGI) To: Royal Norwegian Embassy In Tanzania And The Government Of Tanzania's National.

JGI. (2011). Submitted To Royal Norwegian Embassy-Tanzania By JGI (The Jane Goodall Institute).

JGI. (2011 a). Report On Good Governance Training To Village Council Members 19-28.

JUWAMMA. (n.d.). Katiba Ya Asasi Ya Jumuiya Ya Watunza Msitu Wa Masito (JUWAMMA) (JUWAMMA). JGI, Kigoma.

Luoga. (2010). Report On Training CBO Members On Sustainable Forest Management Practices. In Report On Training CBO Members On Sustainable Forest Management Practices (pp. 20-22).

Makunga, \& Misana. (2017). The Extent and Drivers of Deforestation and Forest Degradation in Masito-Ugalla Ecosystem, Kigoma Region, Tanzania. Open Journal of Forestry, 07(02), 285-305. Retrieved from https://dx.doi.org/10.4236/ojf.2017.72018 10.4236/ojf 2017.72018

Mwanukuzi. (2011). Training Report On Participatory Mapping Of Forests. Training Report On Participatory Mapping Of Forests.

Njahani. (2010). Community Forest Monitors Progress Report (September 2010- June, 2011). JGI, Kigoma. Kigoma: JGI.

Nzunda. (2012). Forest management plan for implementation of a pilot REDD+ project for Masito Community Forest Reserve. Kigoma, Tanzania; Kigoma, Tanzania.

Temu. (2011). Training Report On The Business Management And Customer Care Skills For Stakeholders In Kigoma District REDD Pilot Areas 25th - 28th March 2011 In Kigoma. . In Training Report On The Business Management And Customer Care Skills For Stakeholders In Kigoma District REDD Pilot Areas 25th - 28th. Kigoma.

Yanda. (2010a). Representatives From Community Based, Faith Based Organizations. Kigo.

Yanda. (2010b). Training On Carbon Policies To District. In Training On Carbon Policies To District, Division And Village Government Leaders For Kigoma Rural And Mpanda Districts. Kigoma.

Zahabu. (2008). A Strategy To Involve Forest Communities In Tanzania In Global Climate Policy. In Sinks And Sources: A Strategy To Involve Forest Communities In Tanzania In Global Climate Policy. The Netherlands.

Zahabu. (2011 a). Ground Forest Carbon Assessment Of The Masito Ugalla Ecosystem Pilot Area. In Ground Forest Carbon Assessment of The Masito Ugalla Ecosystem Pilot Area. A Consultancy Report Prepared For The Jane Goodall Institute - Tanzania. Kigoma.

Zahabu. (2011 b). Training Of Trainers On JGI REDD Readiness Project. JGI REDD Readiness Project In Masito-Ugala. 